\title{
Design of the automatic shoe dryer
}

\author{
Ayu Latifah $^{1, *}$, Hilmi Aulawi², and Muhammad Ali Ramdhani ${ }^{3}$ \\ ${ }^{1}$ Sekolah Tinggi Teknologi Garut, Department of Informatics, Jl. Mayor Syamsu No. 1, Garut, 44151, Indonesia \\ ${ }^{2}$ Sekolah Tinggi Teknologi Garut, Department of Industrial Engineering, Jl. Mayor Syamsu No. 1, Garut, 44151, Indonesia \\ ${ }^{3}$ UIN Sunan Gunung Djati Bandung, Department of Informatics, Jl. A. H. Nasution No. 105, Bandung, 40614, Indonesia
}

\begin{abstract}
Shoes are parts of basic human needs. Many of them are typically selected based on different needs of the users. There is always a problem related to shoe care. In many cases, people prefer laundry services to take care of their shoes, but it commonly takes a long duration, about one to two days. Another thing is that the drying process is done through direct sunlight exposure, and that can damage the materials and fade the colors. Therefore, this system is designed and implemented to facilitate the process of drying shoes and protect some shoes that cannot be dried using sunlight. The hardware design is featured with control and software, which are then implemented for further analysis to obtain the desired results. The whole system control is derived from the ladder program within the Programmable Logic Control (PLC). To identify shoes that have been dried or ones that cannot be detected by the SHT11 temperature and humidity sensor, which is connected to the ATmega16 microcontroller as a serial data communication. The implementation resulted in a novelty, namely digital automatic shoe drying system without the use of sunlight.
\end{abstract}

\section{Introduction}

There are many varieties of shoes regarding models and materials to meet the needs of the users [1]. Some particular types of shoes need special care, and this opens the opportunities for shoe laundry services. These laundry services can save the users day, but at the same time, the service usually takes a long time due to drying process that uses direct sunlight needs one or two days [2].

Another problem related to sunlight drying process is that the sunlight can damage the materials, fade the colors, and loosen the adhesive on the sole. On the other hand, the drying process using a fan may make the drying process uneven [3].
That is why this tool is made to automatically and quickly dry shoes. This tool uses a sensor during the drying process. A sensor is a device to detect a condition of an observed object [4] [5]. The sensor detected temperature and humidity in this tool quite accurately. It makes the drying process keep running until the sensor no longer detects the shoes in wet condition.

\section{System designing}

The designing is one of the processes to develop this tool [6] [7]. The purpose of this designing is to determine function, dimension, and circuit of the tool. The tool designing process is illustrated by the Block Diagram as shown in Fig 1.

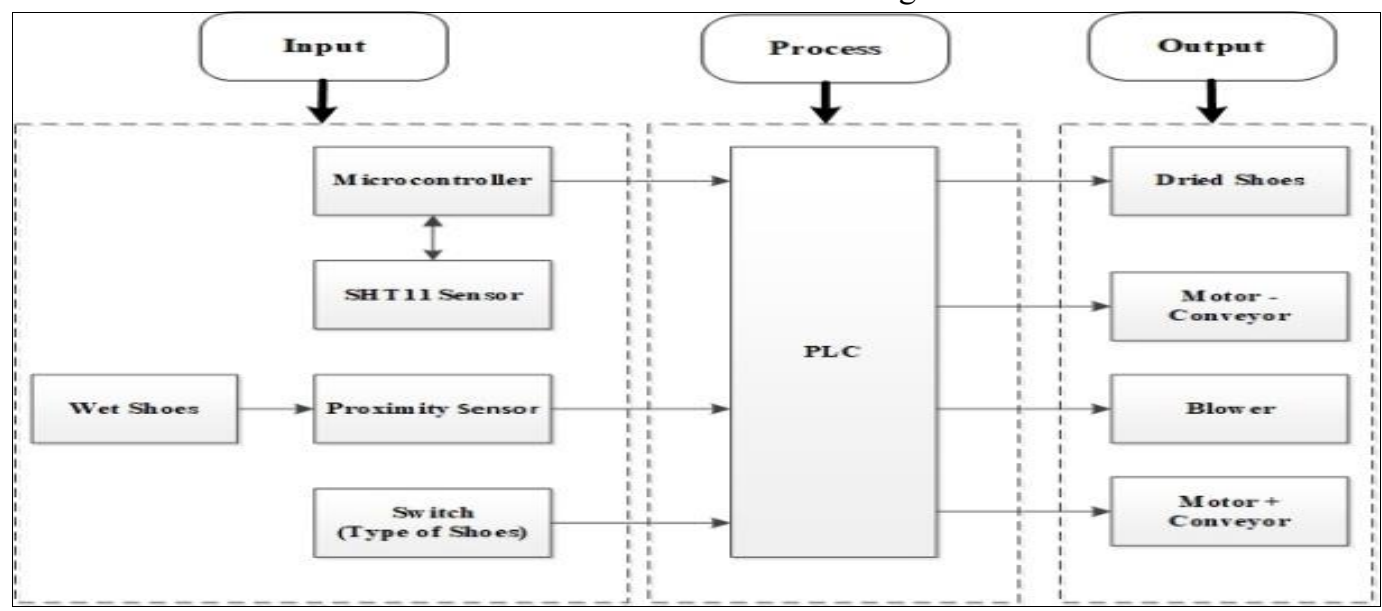

Fig. 1. System Block Diagram.

\footnotetext{
* Corresponding author: ayulatifah@sttgarut.ac.id
} 
The block diagram is designed to provide the general description of how the system will working. Fig 1 shows that this tool works using a temperature and humidity sensor. The temperature reading process and data execution are carried out using a microcontroller. The temperature of $33-34^{\circ} \mathrm{C}$ indicates that the shoes have been dried. That is when the sensor will transfer data to the microcontroller so that one of the ports will have Logic 1. When a microcontroller port generates Logic 1, the relay will be activated so that the PLC controller will receive an AC input. Fig 1 shows that the PLC output is a conveyor using a direct current (DC) motor. The dried shoes are ejected from the drying tool using a reverse DC motor, which is a PLC output.

\section{Measurement and analysis}

\subsection{Hardware designing}

\subsubsection{Temperature control with microcontroller}

A microcontroller is a microprocessing system, in which there are CPU, ROM, RAM, I/O, Clock, and internal equipment [8]. This temperature circuit with microcontroller functions as a processor of data received from the SHT11 sensor module (Fig 1). This sensor is a multi-chip module of temperature and humidity sensor that generates calibrated digital output [9]. The microcontroller output is used as a driver input.

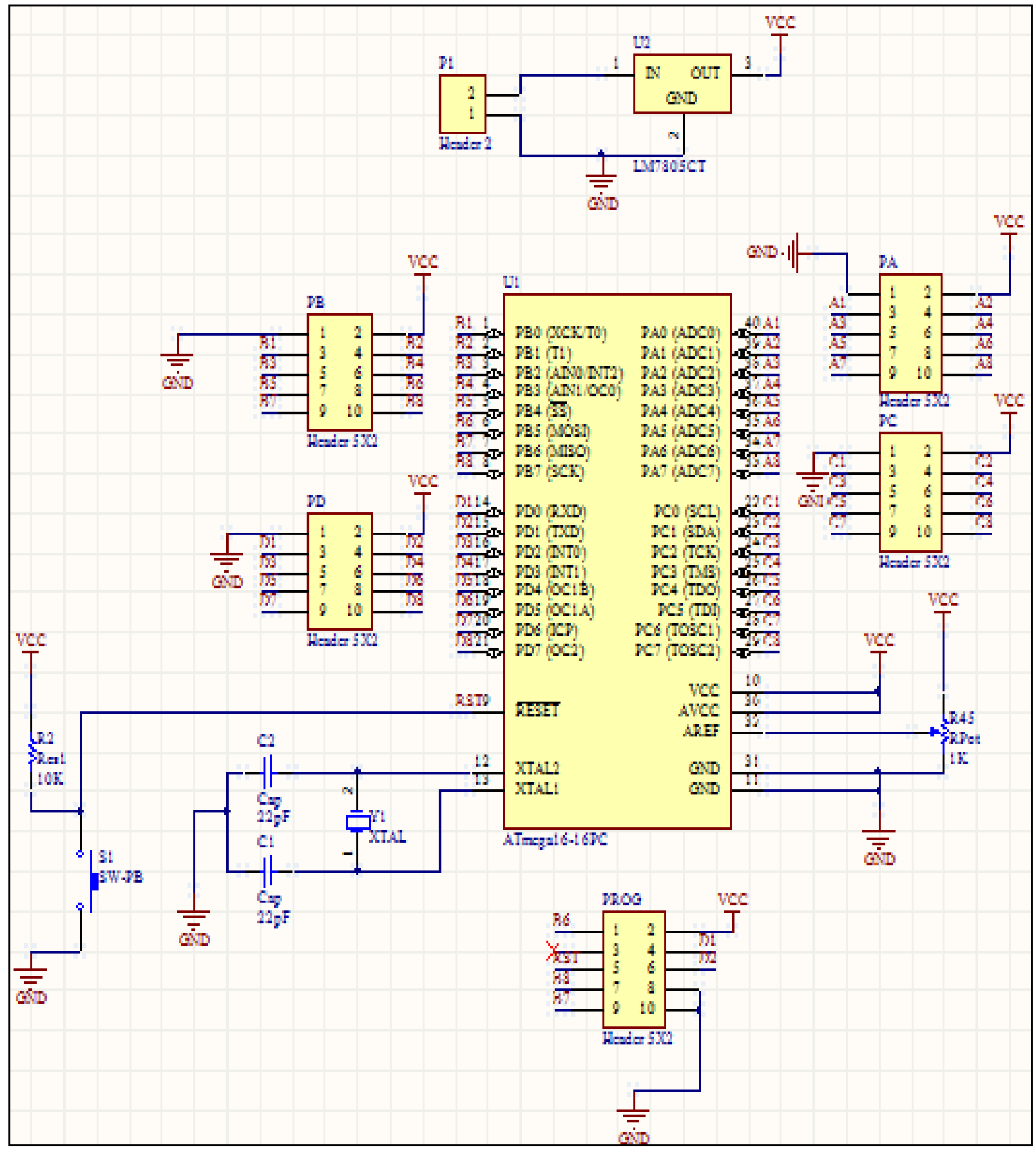

Fig. 2. Temperature Control with Microcontroller Circuit.

\footnotetext{
Corresponding author: ayulatifah@s,sttgarut.ac.id
} 


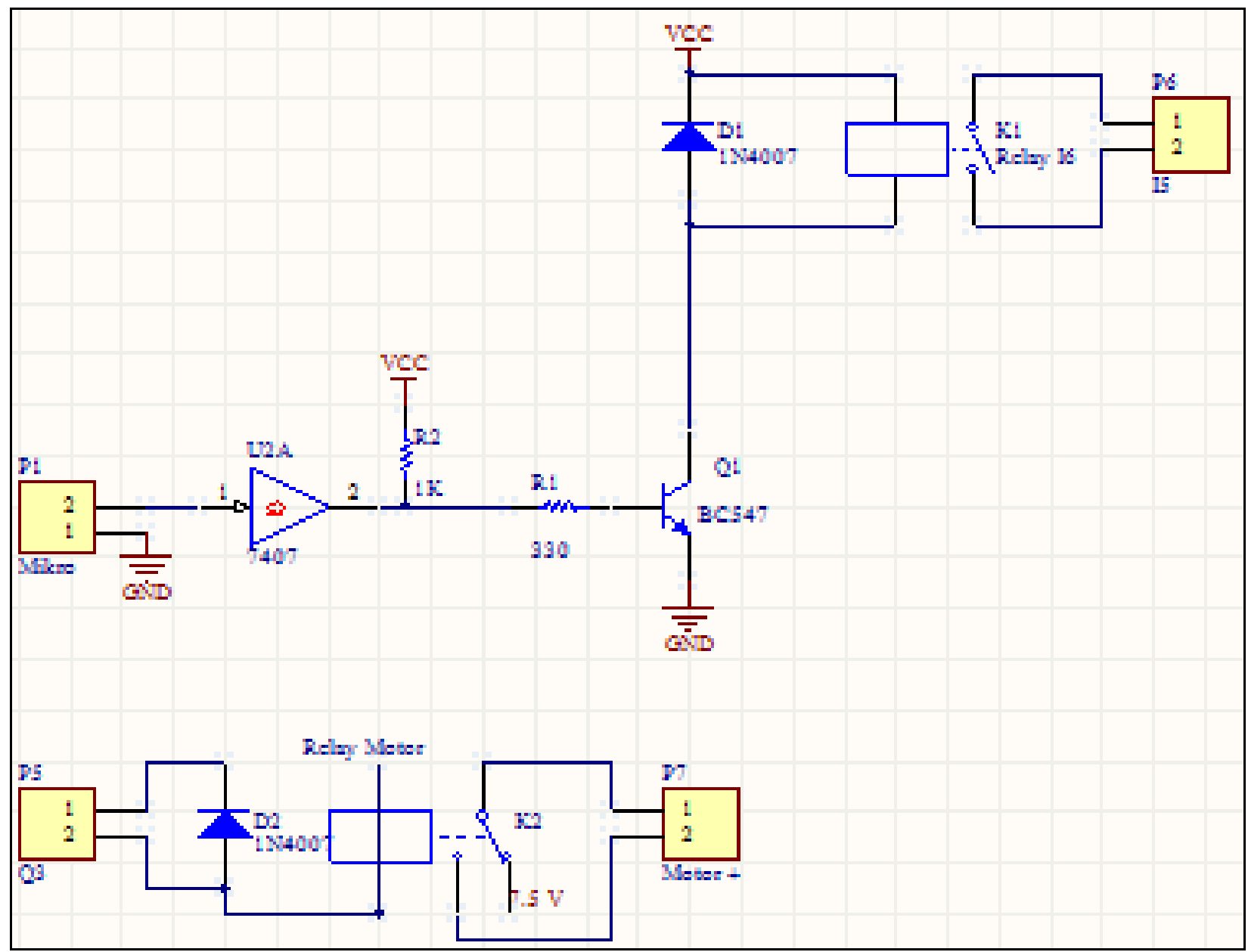

Fig. 3. Relay Driver Circuit.

\subsubsection{Relay driver}

The relay consists of a winding wire wrapped around an iron core that turns into a magnetic field that can attract or reject the spring so that the switch can close and open [10]. This tool serves to switch off the dryer when the SHT11 temperature and humidity sensor detects a specified temperature (Fig 3).

\subsubsection{PLC control}

PLC is an electronic system designed for industry. This system uses a memory that can be programmed to facilitate internal storage from instructions to performs certain functions like logic, sorting, timing, and arithmetic to control various types of machines or processes through digital inputs, outputs and analog [11]. The PLC control circuit is used as a center controller of the whole system (Fig 4). On the PLC output, there are a motor and a heater in a hairdryer, that function as a shoe dryer.

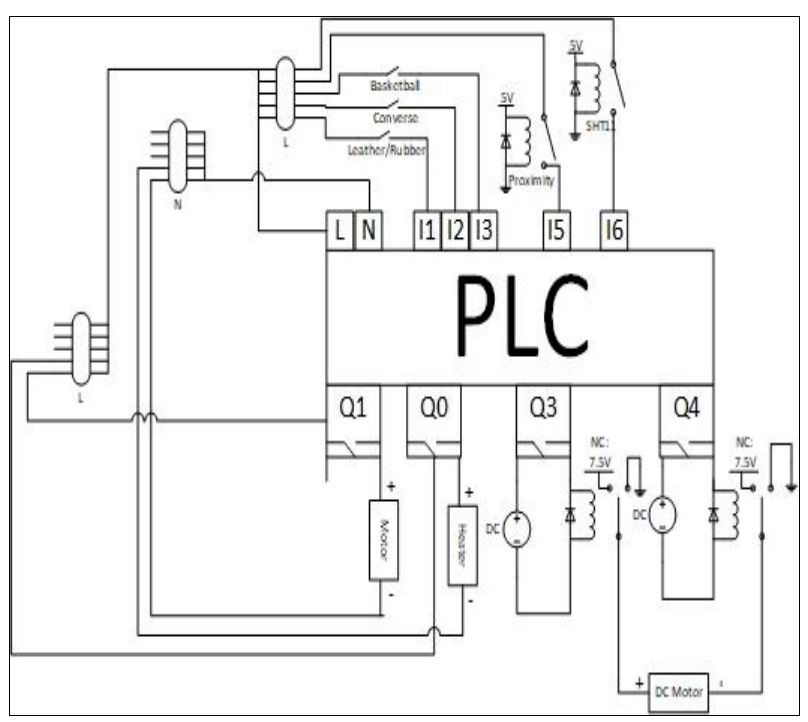

Fig. 4. PLC Control Circuit.

\subsection{Software designing}

\subsubsection{Flowchart}

At this stage, a programming algorithm is designed as shown in Fig 5. This process should be done to facilitate the program realization and analyze errors.

\footnotetext{
${ }^{*}$ Corresponding author: ayulatifah@s,sttgarut.ac.id
} 


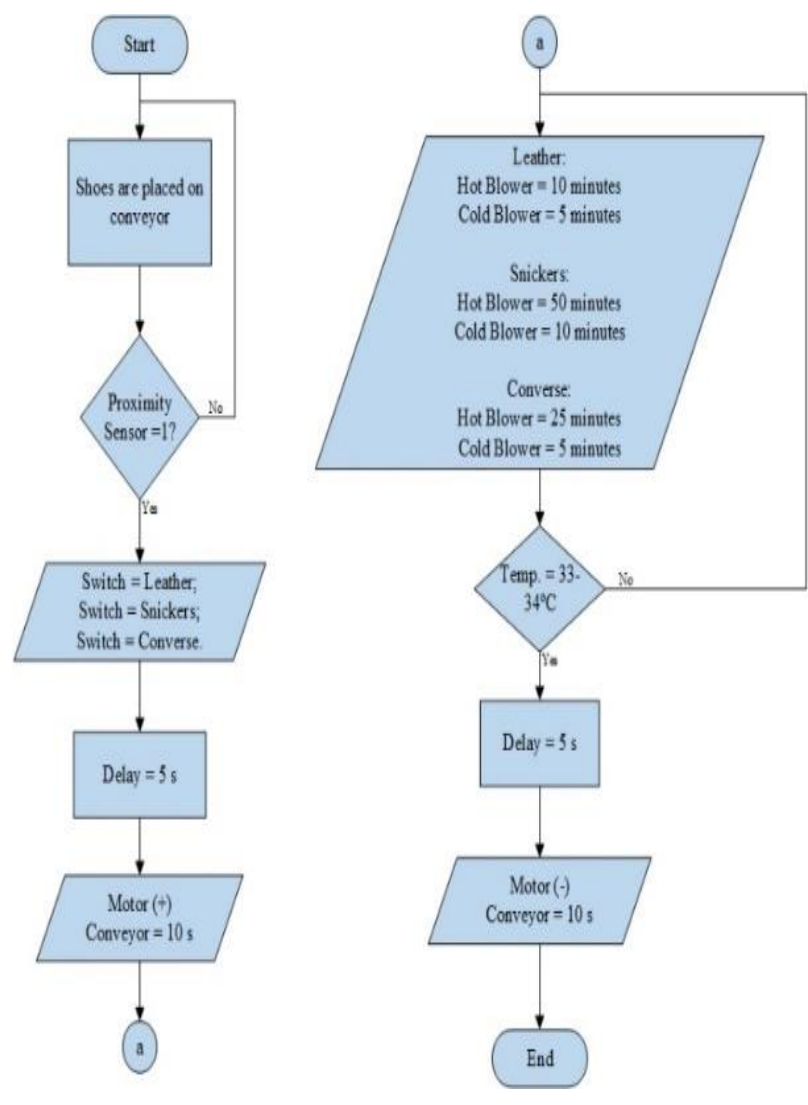

Fig. 5. System Flowchart.

\subsubsection{State diagram}

The state diagram is an illustration of a flow of a ladder program made in a particular condition with an existing prerequisite to facilitate the realization of a ladder program diagram [12]. In this designing, the state diagram is presented in Fig 6.

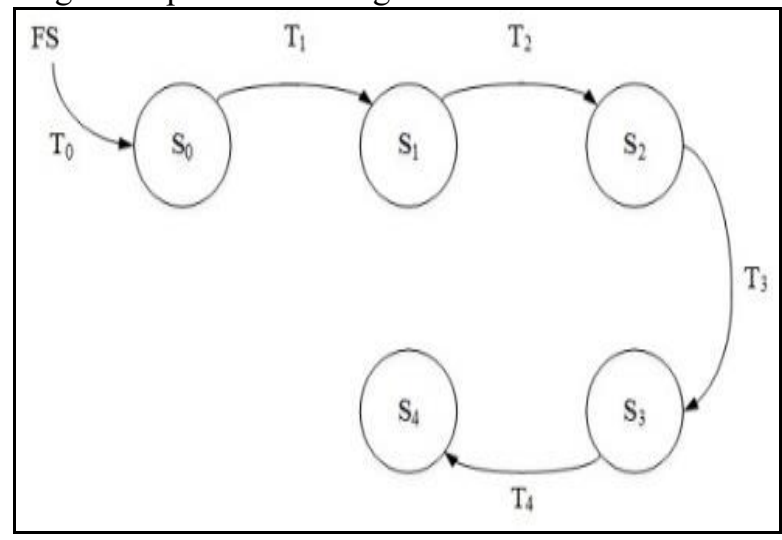

Fig. 6. State Diagram.

\section{Result and analysis}

\subsection{Measurement and analysis of ATmega16 minimum system}

These measurements were performed to figure out the output voltage at the temperature control circuit port. The measurements were carried out five times as shown in Table 1. The results were linear. The accuracy of the microcontroller in generating logics 0 and 1 is stable. When the temperature reaches $33-34^{\circ} \mathrm{C}$, the microcontroller PortB.0 generates the voltage of $4.9 \mathrm{~V}_{\mathrm{DC}}$. And when the temperature is other than those above, the PortB.0 generates the voltage of $0 \mathrm{~V}_{\mathrm{DC}}$.

Table 1. Measurement of ATmega16 Microcontroller.

\begin{tabular}{|l|l|l|l|}
\hline No. & $\begin{array}{c}\text { PortB.0 } \\
\text { Condition }\end{array}$ & \multicolumn{1}{|c|}{$\begin{array}{c}\mathbf{V}_{\mathbf{o}} \\
\left(\mathbf{V}_{\mathbf{D C}}\right)\end{array}$} & \multicolumn{1}{|c|}{$\begin{array}{c}\text { Temperature } \\
\text { Condition }\end{array}$} \\
\hline \multirow{2}{*}{1} & Logic 1 & 4.9 & $33-34^{\circ} \mathrm{C}$ \\
\cline { 2 - 4 } & Logic 0 & 0 & $<33^{\circ} \mathrm{C}$ and $>34^{\circ} \mathrm{C}$ \\
\hline \multirow{2}{*}{2} & Logic 1 & 4.9 & $33-34^{\circ} \mathrm{C}$ \\
\cline { 2 - 4 } & Logic 0 & 0 & $<33{ }^{\circ} \mathrm{C}$ and $>34^{\circ} \mathrm{C}$ \\
\hline \multirow{2}{*}{3} & Logic 1 & 4.9 & $33-34{ }^{\circ} \mathrm{C}$ \\
\cline { 2 - 4 } & Logic 0 & 0 & $<33^{\circ} \mathrm{C}$ and $>34^{\circ} \mathrm{C}$ \\
\hline \multirow{2}{*}{4} & Logic 1 & 4.9 & $33-34^{\circ} \mathrm{C}$ \\
\cline { 2 - 4 } & Logic 0 & 0 & $<33^{\circ} \mathrm{C}$ and $>34^{\circ} \mathrm{C}$ \\
\hline \multirow{2}{*}{5} & Logic 1 & 4.9 & $33-34^{\circ} \mathrm{C}$ \\
\cline { 2 - 4 } & Logic 0 & 0 & $<33{ }^{\circ} \mathrm{C}$ and $>34^{\circ} \mathrm{C}$ \\
\hline
\end{tabular}

\subsection{Measurement and analysis of relay driver circuit}

These measurements were performed to find out the size of input and output voltage at some main components. Table 2 shows that the results of five measurements are stable; i.e., the input and output voltages, from the first to the fifth measurement, are relatively similar, indicating that the system designing process was done very well.

Table 2. Measurement of IC Buffer 7407.

\begin{tabular}{|l|l|l|l|}
\hline No. & \multicolumn{1}{|c|}{ Condition } & \multicolumn{1}{|c|}{$\mathbf{V}_{\mathbf{D C}}$} & \multicolumn{1}{|c|}{ Note } \\
\hline \multirow{2}{*}{1} & Input & 1.446 & PortB.0 Micro \\
\cline { 2 - 4 } & Output & 4.6 & PortB.0 Micro \\
\hline \multirow{2}{*}{2} & Input & 1.452 & PortB.0 Micro \\
\cline { 2 - 4 } & Output & 4.61 & PortB.0 Micro \\
\hline \multirow{2}{*}{3} & Input & 1.453 & PortB.0 Micro \\
\cline { 2 - 4 } & Output & 4.6 & PortB.0 Micro \\
\hline \multirow{2}{*}{4} & Input & 1.451 & PortB.0 Micro \\
\cline { 2 - 4 } & Output & 4.62 & PortB.0 Micro \\
\hline \multirow{2}{*}{5} & Input & 1.461 & PortB.0 Micro \\
\cline { 2 - 4 } & Output & 4.61 & PortB.0 Micro \\
\hline
\end{tabular}

\subsection{Measurement and analysis of blower/ hairdryer}

These measurements were performed to read temperature when the air is warm and cold using the SHT11 sensor. Table 3 shows that the results of several 
measurements are relatively similar. When the hairdryer is turned on, the $\mathrm{AC}$ voltage from the source is reduced. It is because some of AC voltage is used to turn on the hairdryer motor [13].

Table 3. Measurement of Blower/Hairdryer.

\begin{tabular}{|c|l|c|c|}
\hline No. & \multicolumn{1}{|c|}{$\begin{array}{c}\text { Hairdryer } \\
\text { Condition }\end{array}$} & $\mathbf{V}_{\text {in }}\left(\mathbf{V}_{\text {AC }}\right)$ & $\begin{array}{c}\text { Temperature } \\
\text { Condition }\end{array}$ \\
\hline 1 & $\begin{array}{l}\text { When the air } \\
\text { temperature is high }\end{array}$ & 208.6 & $40-40.6^{\circ} \mathrm{C}$ \\
\cline { 2 - 4 } & $\begin{array}{l}\text { When the air } \\
\text { temperature is low }\end{array}$ & 212.8 & $36-37^{\circ} \mathrm{C}$ \\
\hline \multirow{2}{*}{2} & $\begin{array}{l}\text { When the air } \\
\text { temperature is high }\end{array}$ & 210.4 & $40-40.6^{\circ} \mathrm{C}$ \\
\cline { 2 - 4 } & $\begin{array}{l}\text { When the air } \\
\text { temperature is low }\end{array}$ & 213.2 & $36-37^{\circ} \mathrm{C}$ \\
\hline \multirow{2}{*}{3} & $\begin{array}{l}\text { When the air } \\
\text { temperature is high }\end{array}$ & 208.5 & $40-40.6^{\circ} \mathrm{C}$ \\
\cline { 2 - 4 } & $\begin{array}{l}\text { When the air } \\
\text { temperature is low }\end{array}$ & 212.4 & $36-37^{\circ} \mathrm{C}$ \\
\hline \multirow{2}{*}{4} & $\begin{array}{l}\text { When the air } \\
\text { temperature is high }\end{array}$ & 209.5 & $40-40.6^{\circ} \mathrm{C}$ \\
\cline { 2 - 4 } & $\begin{array}{l}\text { When the air } \\
\text { temperature is low }\end{array}$ & 213.2 & $36-37^{\circ} \mathrm{C}$ \\
\hline \multirow{2}{*}{5} & $\begin{array}{l}\text { When the air } \\
\text { temperature is high }\end{array}$ & 210.2 & $40-40.6^{\circ} \mathrm{C}$ \\
\hline $\begin{array}{l}\text { When the air } \\
\text { temperature is low }\end{array}$ & 212.5 & $36-37^{\circ} \mathrm{C}$ \\
\hline
\end{tabular}

\section{Conclusion and suggestion}

After performing the tests, measurements, and analyses, it can be concluded that the PLC works by the ladder program diagram. The tool uses two controllers, PLC, and microcontroller. It is because the temperature sensor is controlled by a microcontroller, and the whole tool is controlled by PLC. The drying time depends on the types of shoes. The longest is one hour.

It is expected that there will be further developed for this tool to be able to be implemented not only in the industrial area but also in a residential area by minimizing the mechanics of the tool. The sensor reading can be used to detect dry shoes so that when they are inserted into the dryer, the drying process won't be performed. Timer and temperature reading can be displayed. The sensor can automatically selecting the type of shoes. The tool can also be equipped with Human Machine Interface (HMI) as an indicator panel. The drying process can be done with multiple shoes simultaneously. The blower consumes small voltage. The tool is also featured with a rack to put dried shoes.

\section{References}

1. W. N. Laluyan, S. S. Pangemanan, and F. G. Worang, "The Effect of Advertising, Perceived Quality and Brand Awareness on Consumer Purchase Intention (Case Study: ADIDAS Sport Shoes)," J. Riset Ekonomi, Manajemen, Bisnis dan Akuntansi, vol. 5, no. 2, (2017).

2. J. Y. Che, J. M. Cheon, J. H. Chun, C. C. Park, Y. H. Lee and H. D. Kim, "Preparation and Properties of Emulsifier Solvent Free Slightly Crosslinked Waterborne Polyurethane-Acrylic Hybrid Emulsions for Footwear Adhesives (III) Effect of Trimethylol Propane (TMP) / Ethylene Diamine (EDA) Content," J. of Adhesion Science and Technology, 1-16, (2017).

3. D. J. Cho and Y. R. Jeong, "Design of Smart Shoe Box Based on IOT," in In Ubiquitous and Future Networks (ICUFN), 2017 Ninth International Conference on (pp. 607-609). IEEE, (2017).

4. L. Kamelia, M. A. Ramdhani, A. Faroqi and V. Rifadiapriyana, "Implementation of Automation System for Humidity Monitoring and Irrigation System," IOP Conference Series: Materials Science and Engineering, vol. 288, no. 1, p. 012092, (2018).

5. N. Fajrin, I. Taufik, N. Ismail, L. Kamelia and M. A. Ramdhani, "On the Design of Watering and Lighting Control Systems for Chrysanthemum Cultivation in Greenhouse Based on Internet of Things," IOP Conference Series: Materials Science and Engineering, 288, no. 1, p. 012105, (2018).

6. Student, B. E, "Cloud Computing for Agriculture," Int. J. of Engineering Science, 10996, (2017).

7. D. S. Maylawati, W. Darmalaksana and M. A. Ramdhani, "Systematic Design of Expert System Using Unified Modelling Language," IOP Conference Series: Materials Science and Engineering, vol. 288, no. 1, p. 012047, (2018).

8. S. R. Laney, "A General-Purpose MicrocontrollerBased Framework for Integrating Oceanographic Sensors, Instruments, and Peripherals," J. of Atmospheric and Oceanic Technology, 34(2), pp. 415-427, (2017).

9. I. Sugriwan and O. Soesanto, "Development of TGS2611 Methane Sensor and SHT11 Humidity and Temperature Sensor for Measuring Greenhouse Gas on Peatlands in South Kalimantan, Indonesia," Int. J. of Physics: Conference Series (Vol. 853, No. 1, p. 012006), (2017).

10. P. Shinde, G. Shiradhonkar and S. Saluke, "Wireless Home Automation Using Wi-Fi Enable Switch and Mobile," I. J. of Interdisciplinary Research, 3(3), (2017).

11. P. Abhishesh, B. S. Ryuh, Y. S. Oh, H. J. Moon and R. Akanksha, "Multipurpose Agricultural 
Robot Platform: Conceptual Design of Control System Software for Autonomous Driving and Agricultural Operations Using Programmable Logic Controller," World Academy of Science, Engineering and Technology, I. J. of Mechanical, Aerospace, Industrial, Mechatronic and Manufacturing Engineering, 11(3), pp. 496-500, (2017).

12. J. C. Quezada, J. Medina, E. Flores, J. S. Tuoh, A. E. Solís and V. Quezada, "Simulation and Validation of Diagram Ladder-Petri Nets," The I. $J$. of Advanced Manufacturing Technology, 88(58), pp. 1393-1405, (2017).

13. A. A. Gandhi, Y. Deng, R. Williamson and S. G. Latham, "A New Drying Rate Measurement Method for Hair Dryers," I. J. of Engineering and Technology, 7(4), (2017). 